\title{
Evaluation of the allelopathic potential of water-soluble compounds of barley (Hordeum vulgare L. subsp. vulgare) and great brome (Bromus diandrus Roth.) using a modified bioassay
}

\author{
Imen Bouhaouel ${ }^{(1,2)}$, Aurélie Gfeller ${ }^{(1,3)}$, Marie-Laure Fauconnier ${ }^{(4)}$, Benjamin Delory ${ }^{(1)}$, \\ Hajer Slim Amara ${ }^{(2)}$, Patrick du Jardin ${ }^{(1)}$ \\ (1) University of Liège - Gembloux Agro-Bio Tech. Plant Biology Laboratory. Passage des Déportés, 2. BE-5030 Gembloux \\ (Belgium).E-mail: imenbouhaouel@gmail.com \\ (2) University of Carthage. National Agronomic Institute of Tunisia. Department of Agronomy and Plant Biotechnology. \\ Genetics and Cereal Breeding Laboratory. Charles Nicolle Street, 43. TN-1082 Tunis Mahrajène (Tunisia). \\ (3) Swiss Federal Research Station Agroscope Changins Wädenswil AC. CH-1260 Nyon (Switzerland). \\ (4) University of Liège - Gembloux Agro-Bio Tech. General and Organic Chemistry Laboratory. Passage des Déportés, 2. \\ BE-5030 Gembloux (Belgium).
}

Received on December 29, 2015; accepted on June 16, 2016.

Description of the subject. The present study focuses on the description of the allelopathic interactions between wild and crop species that may occur in a given ecosystem.

Objectives. The objective is the evaluation of the allo- and autoinhibition activity of root exudates of barley (Hordeum vulgare L. subsp. vulgare) and great brome (Bromus diandrus Roth.) seedlings by water-soluble allelochemicals.

Method. The allelopathic activities of five Tunisian barley genotypes (modern varieties and landraces), one Saudi Arabian barley landrace and great brome were assessed using a modified laboratory bioassay named "seedling-after-seedling agar method".

Results. The barley or the great brome reduced, to a greater extent, the root growth compared to the shoot growth of receiver species. The response of the root system architecture of the great brome towards barley root exudates was studied in detail. All the measured root traits were highly sensitive to the presence of barley. In our conditions, the allelopathic activity of barley root exudates had no apparent relationship with the size of the root and a prominent action of genetic determinants in the allelopathic potential between genotypes is proposed. The alloinhibitory activity of barley or great brome root exudates deferred between the receiver species but was always higher than the autoinhibition potential. The autoinhibition in barley proved to depend on whether the genotypes used as donor and receiver are identical or different, suggesting a specific interaction of allelochemicals with the receiver plant. These molecules seem to be the main actors in the allelopathic barley potential as external factors such variations of $\mathrm{pH}$ have no evident relevance in the inhibition process.

Conclusions. Barley and great brome exude molecules in their surroundings. This affects the growth of the receiver plants, suggesting that these compounds might contribute to the plant community dynamics.

Keywords. Allelopathy, Hordeum vulgare, Bromus diandrus, $\mathrm{pH}$, root exudates, root systems.

Évaluation du potentiel allélopathique des composés hydrosolubles de l'orge (Hordeum vulgare L. subsp. vulgare) et du grand brome (Bromus diandrus Roth.) moyennant un bio-essai modifié

Description du sujet. La présente étude se focalise sur la description des interactions allélopathiques entre des espèces sauvages et cultivées qui peuvent survenir dans un écosystème donné.

Objectifs. L'objectif est l'évaluation de l'activité d'auto- et d'alloinhibition des exsudats racinaires de l'orge (Hordeum vulgare L. subsp. vulgare) et du grand brome (Bromus diandrus Roth.) via les allélochimiques hydrosolubles.

Méthode. Les activités allélopathiques de cinq génotypes tunisiens d'orge (variétés modernes et orges locales), d'une orge locale d'Arabie saoudite et du grand brome ont été évaluées moyennant un bio-essai modifié nommé « seedling-after-seedling agar method». 
Résultats. L'orge et le grand brome ont réduit dans une grande mesure la croissance des racines des espèces receveuses comparativement à celle des pousses. La réponse de l'architecture du système racinaire du grand brome à l'égard des exsudats racinaires de l'orge a été étudiée en détail. Il s'est avéré que tous les traits des racines analysés ont été très sensibles en présence de l'orge. Dans nos conditions, l'activité allélopathique des exsudats racinaires de l'orge n'avait aucune relation apparente avec la taille des racines et une action prépondérante des déterminants génétiques dans le potentiel allélopathique entre les génotypes est ainsi proposée. L'activité d'alloinhibition des exsudats racinaires de l'orge ou du grand brome était différente entre les espèces receveuses mais toujours plus élevée par rapport au potentiel d'autoinhibition. L'autoinhibition chez l'orge a été dépendante des génotypes utilisés comme donneurs et receveurs qui étaient identiques ou différents, suggérant ainsi une interaction spécifique des allélochimiques avec la plante receveuse. Ces molécules semblent être les principaux acteurs du potentiel allélopathique chez l'orge, étant donné que les facteurs externes comme les variations du pH n'ont aucune pertinence évidente dans le processus d'inhibition.

Conclusions. L'orge et le grand brome relâchent dans leur environnement des molécules qui affectent la croissance des plantes receveuses, suggérant ainsi que ces composés pourraient contribuer à la dynamique des communautés végétales.

Mots-clés. Allélopathie, Hordeum vulgare, Bromus diandrus, pH, exsudat racinaire, système racinaire.

\section{INTRODUCTION}

Negative interactions among plants are mediated by two biological phenomena: competition for limited resources, such as space, light, water, or nutrients, and allelopathy, the chemical interaction between plants (Olofsdotter et al., 2002). The allelopathy phenomenon includes both harmful and beneficial biochemical interactions between all types of plants by the production of secondary metabolites, commonly called allelochemicals, into the surrounding environment (Rice, 1984). Allotoxicity and autotoxicity refer to situations where the donor plant, releasing allelochemical inhibitors, and the receiver plant, showing reduced seed germination and/or plant growth as a response to these allelochemicals, belong to different or the same species, respectively (Putnam, 1985; Singh et al., 1999).

These chemical interactions are assumed to play significant roles at the community and ecosystem levels, participating to plant fitness in both natural and managed ecosystems (Chou, 1999). In agroecosystems, farming practices, i.e. monoculture or overseeding (Chon et al., 2006), were observed to favor autotoxicity, resulting in soil-sickness and losses in plant productivity and crop yield (Singh et al., 1999). Regarding allotoxicity, the allelopathic potential of crop plants was exploited by alternative and eco-friendly weed control strategies (Belz, 2007). Allelopathic weeds can also affect crops in a number of ways, like delaying or preventing seed germination and reducing seedling growth. Most allelopathic evidence has separately focused on the effect of crops on weeds, crops on crops or weeds on crops (Chon et al., 2010), but the scientific literature is rather poor concerning the description of all the allelopathic interactions in a given ecosystem, more especially through the root exudates. Furthermore, the auto- and alloinhibition activities of root exudates were never compared in wild or in crop species.
Despite the ecological and agronomic importance of allelopathy, the mechanisms involved are still poorly understood. Roots have the capacity to alter both physical and chemical characteristics of the rhizosphere (Darrah, 1993), which in combination may participate to the allelopathic effects. For example, the root exudates-mediated $\mathrm{pH}$ change is a critical chemical parameter that acts on plant growth by affecting the availability of nutrients and toxic elements in the soil (Hinsinger et al., 2003). Lower pH values tend to decrease the availability of phosphorus, calcium, potassium or magnesium (Fageria et al., 1989; Rajan et al., 1997) and to increase the solubility of aluminum, cadmium or manganese (Hue et al., 2001; Shamsi et al., 2007). Acidic environments may also inhibit plant growth by affecting the plasmalemma of root cells (Brix et al., 2002). In addition, the $\mathrm{pH}$ has been shown to play a significant role in the uptake of phenolics - which include many allelochemicals - and in the expression of their toxicity (Blum et al., 1985). Similarly, the variation of $\mathrm{pH}$ impacts enzymatic activity (Singh et al., 2014). It is noteworthy that most allelopathic studies describing the toxicity of root exudates failed to distinguish between the effects of $\mathrm{pH}$ variation and the direct toxicity of the released compounds.

Allelopathic properties have been demonstrated in barley (Hordeum vulgare L. subsp. vulgare), like in many cereal crops, and shown to involve diverse mechanisms such as residue decomposition from various plant tissues (Gubbels et al., 1989), root exudation (Bertholdsson, 2004; Bouhaouel et al., 2015), volatile organic compounds (VOCs) emissions from above and belowground parts of the plant (Ninkovic, 2003; Gfeller et al., 2013). Barley residues are autotoxic, making barley-barley cropping sequence inappropriate (Oueslati et al., 2005). This species produces a complex mixture of allelochemicals (phenolics, alkaloids, cyanoglucosides and polyamines) 
that seems to be specially diversified, as compared with e.g. wheat (Baghestani et al., 1999; Kremer et al., 2009). Altogether, these observations make barley an interesting model of allelopathy in crop plants.

In this paper, we have evaluated the chemical interactions via water-soluble compounds of root exudates between and within cultivated barley (Hordeum vulgare L. subsp. vulgare) and great brome (Bromus diandrus Roth., syn. Bromus rigidus Roth. subsp. gussonii Parl.), a troublesome grassy weed. This weed is largely distributed in Tunisian cereal crops and causes significant (20-50\%) yield losses (Souissi et al., 2001). The description of the allelopathic interactions between these crop and wild species would allow to determine the most efficient genotypes of barley that might be recommended for farmers or considered in breeding programs of Tunisian cultivated barley for a biological weed control. This study aimed also to understand some underlying allelopathic mechanisms, e.g. the role of the $\mathrm{pH}$ as influenced by root exudates, or the vigor of root system in the allelopathic process.

With this aim, we have adopted the "seedlingafter-seedling agar method", an experimental protocol modified from the "equal-compatment-agar method" of Wu et al. (2000), where the donor and the receiver species of allelochemicals are grown sequentially, to assess the allelopathic potential of water-soluble compounds and to minimize resource competition. As reported by Nilsson (1994), it is indeed challenging to distinguish allelopathic effects from resource competition. This choice was based on a previous work which focused on the comparison of "seed-toseed" and "seed-after-seed" experimental protocols (Bouhaouel et al., 2015). The present method allows us:

- to determine the allelopathic potential of watersoluble compounds of donor species on the receiver species in a more advanced stage of growth as compared to the "seed-after-seed" protocol,

- to expose the receiver species for a longer time to allelochemicals,

- to monitor root growth and architecture of receiver species developing in the water agar medium.

In addition, the "seedling-after-seedling agar method" is a suitable protocol for the common chickweed (Stellaria media L.) used as weed reference (Overland, 1966) and receiver species of barley compounds. This test was impossible using the "seedto-seed" (photodormant seeds) and has not yielded conclusive results using the "seed-after-seed".

In this work, we assess:

- the allotoxicity potential of barley (Hordeum vulgare L.) and great brome (Bromus diandrus Roth.) root exudates on each other mediated by water-soluble allelochemicals using a modified bioassay,
- the variation in root system architecture (RSA) of great brome in response to barley root allelochemicals considering that root architecture is a highly plastic and environmentally responsive trait (Kellermeier et al., 2013),

- the autotoxicity effect in both species,

- the possible relationship between root vigor of different barley genotypes and their allelopathic potential,

- the importance of $\mathrm{pH}$ on the expression of the allelopathic potential.

\section{MATERIALS AND METHODS}

\subsection{Plant materials}

Seeds of five Tunisian barley (Hordeum vulgare L. subsp. vulgare) genotypes, and one genotype introduced in Tunisia from Saudi Arabia ('Saudi') were obtained from the National Agronomic Institute of Tunisia (Table 1). The most cultivated modern varieties, 'Rihane' and 'Manel', were chosen in this study (El Felah, 2011; Gharbi et al., 2013). In addition, the modern variety 'Tej' and barley landraces better adapted to local environmental constraints, including water (El Faleh et al., 1985) and saline stress (Hammami et al., 2016), were used. Seeds of great brome (Bromus diandrus Roth., syn. Bromus rigidus Roth. subsp. gussonii Parl.) were collected from infested sites in the North of Tunisia, more specifically in the region of Beja (between 36 $42^{\prime} 07.0^{\prime \prime} \mathrm{N}, 9^{\circ} 12^{\prime} 46.3^{\prime \prime} \mathrm{E}$ and $\left.36^{\circ} 41^{\prime} 00.2^{\prime \prime} \mathrm{N}, 9^{\circ} 13^{\prime} 09.8^{\prime \prime} \mathrm{E}\right)$. Seeds of the common chickweed (Stellaria media L.) were purchased from the company Arbiotech (Rennes, France).

\subsection{Sterilization and pre-germination}

All the seeds were surface-sterilized to avoid microbial contamination potentially influencing the stability of allelochemicals (Inderjit, 2005). Briefly, the barley seeds were incubated in $\mathrm{H}_{2} \mathrm{SO}_{4}(50 \% \mathrm{v} / \mathrm{v})$ for $1 \mathrm{~h}$ and

Table 1. Characteristics and origin of the used barley genotypes - Caractéristiques et origine des génotypes d'orge utilisés.

\begin{tabular}{llll}
\hline Genotype & Type & Origin & $\mathbf{N}^{\circ}$ row \\
\hline 'Manel' & Modern variety & Tunisia & 6 \\
'Rihane' & Modern variety & Tunisia & 6 \\
'Tej' & Modern variety & Tunisia & 2 \\
'Ardhaoui' & Landrace & Tunisia & 6 \\
'Arbi' & Landrace & Tunisia & 6 \\
'Saudi' & Landrace & Saudi Arabia & 2 \\
\hline
\end{tabular}


washed five times in sterile bidistilled water. Seeds were subsequently shaken in $\mathrm{AgNO}_{3}(1 \%$ w/v) at $200 \mathrm{rpm}$ for $20 \mathrm{~min}$ and rinsed successively with $\mathrm{NaCl}$ $(1 \% \mathrm{w} / \mathrm{v})$, sterile bidistilled water, $\mathrm{NaCl}(1 \% \mathrm{w} / \mathrm{v})$ and five times with sterile bidistilled water (Lanoue et al., 2010).

Great brome and the common chickweed seeds were sterilized according to Wu et al. (2007). The seeds were surface-sterilized by soaking them in ethanol $(70 \% \mathrm{v} / \mathrm{v})$ for $2.5 \mathrm{~min}$ and were rinsed four times with sterile bidistilled water. Seeds were then soaked in sodium hypochlorite $(2.5 \% \mathrm{v} / \mathrm{v})$ solution for $15 \mathrm{~min}$ followed by five rinses in sterile bidistilled water.

After sterilization, the barley and the great brome seeds were pre-germinated on moist sterile filter paper and were placed in darkness in a growth chamber at $22{ }^{\circ} \mathrm{C}$ for 72 and $96 \mathrm{~h}$, respectively. However, the common chickweed seeds were incubated for 7 days with a light/dark cycle of $16 / 8 \mathrm{~h}$, at a temperature of $22{ }^{\circ} \mathrm{C}$ and inflorescent light of $3.56 \pm 0.16 \mathrm{x}$ $10^{3}$ lux. Germinated seeds were selected for bioassay experiments.

\subsection{Allelopathic activity of barley against weeds}

The allelopathic activity of barley against two weed species, namely great brome and common chickweed was tested according to the "seedling-after-seedling agar method". This method derived from the "equalcompartment-agar-method" (ECAM) of Wu et al. (2000) where seeds of the allelochemicals-donor species are grown together with the receiver species. However, in our experiments, seeds of the donor and receiver species are grown sequentially and not synchronously, as follows. Pre-germinated seeds of the barley were uniformly selected and aseptically sown on the entire agar surface with three densities $(5,12$ and 16 seeds/beaker), in 1.51 glass beaker (le Parfait, Villeurbanne, France) filled with $90 \mathrm{ml}$ of $0.3 \%$ water agar. The beakers were sealed with plastic film and placed in a controlled growth chamber with a daily light/dark cycle of $16 / 8 \mathrm{~h}$, at temperature of $22^{\circ} \mathrm{C}$ and influorescent light of $3.56 \pm 0.16 \times 10^{3}$ lux. After 7 days, the barley seedlings were removed and replaced by 10 pre-germinated weed seeds (great brome or common chickweed) and aseptically sown on the agar surface. Thereafter, the beakers were again sealed and placed back in the growth chamber. A treatment without barley seeds was used as control. This bioassay was arranged as a completely randomized block design with five replicates for each treatment. After 10 days, the greatest root and shoot lengths of weed seedlings were measured.

In order to assess the effect of barley allelochemicals on the root architecture of the receiver species using the same experimental protocol, the 'Ardhaoui' genotype was chosen based on its high allelopathic potential against the great brome (Bouhaouel et al., 2015). 'Ardhaoui' seeds were sown with one density (16 seeds/beaker) on the surface of agar medium. A beaker without donor seeds was used as control. This experiment was also performed with five replicates for each treatment. After 10 days, root system architecture (RSA) of 5 great brome seedlings per repetition was analyzed using architect software (Delory et al., 2016). Cereal species are generally characterized by the primary root that emerges quickly from the seed after germination and by the seminal roots that emerge after few days forming the embryonic root system. Thereafter, lateral roots arise on the primary or seminal roots and can produce successively higher order branched roots, up to third or fourth order (e.g. the first-order lateral roots are directly located on the primary or seminal roots and those of second-order are located on the first-order lateral roots (Orman-Ligeza et al., 2013; Rich et al., 2013). In this experiment, eight parameters were considered: total root length $(\mathrm{cm})$, primary root length $(\mathrm{cm})$, total length of first-order lateral roots $(\mathrm{cm})$, total length of second-order lateral roots $(\mathrm{cm})$, number of first-order lateral roots, number of second-order lateral roots, density of first-order lateral roots $\left(\mathrm{cm}^{-1}\right)$ and growth rate of root system $\left(\mathrm{cm} \cdot \mathrm{day}^{-1}\right)$. This last parameter was calculated as the difference between the total root system length at time $t$ and $t_{-1}$ divided by the difference between the root system age at time $t_{\text {and }} t_{-1}$.

\subsection{Allelopathic activity of barley against barley of the same or different genotype}

The allelopathic activity of barley against itself was tested according to the "seedling-after-seedling agar method". In this bioassay, 'Manel' (low allelopathic potential) and 'Ardhaoui' (high allelopathic potential) (Bouhaouel et al., 2015) were used as donor genotypes of allelochemicals against either the same genotype or the other one ('Manel' or 'Ardhaoui'). Donor seeds were sown with one density (16 seeds/beaker) on the surface of agar medium. A beaker without donor seeds was used as control. The experiment was arranged as a completely randomized block design with five replicates for each treatment.

\subsection{Allelopathic activity of great brome against itself and against barley}

The alloinhibition activity of the great brome was evaluated against the two barley genotypes 'Manel' (low allelopathic potential) and 'Ardhaoui' (high allelopathic potential) (Bouhaouel et al., 2015). The same provenance of great brome was used for analyzing the autoinhibition activity of this weed. The 
experimental set-up was identical to the one mentioned above.

\subsection{Relation between root vigor and toxicity of barley root exudates}

According to the "seedling-after-seedling agar method", 16 pre-germinated seeds of the Tunisian barley genotypes ('Manel', 'Rihane', 'Tej', 'Ardhaoui' and 'Arbi') were sown on the agar medium. The experiment was performed with five replicates for each genotype. After 7 days, the length of the longest root, presumably the primary root (Rich et al., 2013) was measured for each barley plant. Thereafter, a correlation between barley root length data and their inhibitory action on the root of great brome and common chickweed seedlings was done.

\subsection{Effect of the growing medium $\mathrm{pH}$ on phytotoxicity}

This experiment was made to determine to what extent the observed inhibition effect of barley roots can be explained by their action on the $\mathrm{pH}$ of the agar growing medium, independently of the toxicity of released allelochemicals. In these conditions, 'Ardhaoui' genotype was used as donor species using two densities ( 5 and 16 seeds/beaker). The $\mathrm{pH}$ of the medium was measured using a pH meter (WTW 315i, Weilheim, Germany) after the initial growth period of the donor species, and before the receiver species were introduced. Two treatments were applied in the presence $(\approx \mathrm{pH}=$ 6.12) and in the absence $(\mathrm{pH}=6.10)$ of potassium phosphate buffer, where quantities were adjusted in accordance with barley densities. The buffer (1 M stock solution) was added in the agar medium before autoclaving (to get final concentration in the medium of $3.0 \mathrm{mM}$ and $3.5 \mathrm{mM}$ in the beakers receiving 5 and 16 barley seeds, respectively). Beakers without barley seeds and with buffer in the medium were used as controls. This bioassay was arranged as a completely randomized block design with four replicates for each treatment and repeated twice over time. After 7 days, the barley seedlings were replaced by 10 pre-germinated seeds of great brome. The greatest root and shoot lengths of weed seedlings were recorded after 10 days of growth.

The impact of this buffer $(3.0$ and $3.5 \mathrm{mM})$ on the growth of 10 pre-germinated 'Ardhaoui' seeds was tested. Beakers without buffer in the agar growing medium were used as controls and the length of the root and shoot were also measured after 7 days.

\subsection{Statistical analysis}

Experimental data were subjected to Analysis of Variance (ANOVA) using SAS package (SAS V9.1) with the Least Significant Difference (LSD) test at a 5\% level of probability. The percentage of inhibition on the growth of receiver plant was calculated as (Control Treatment)/Control*100. Since interaction is not significant between seed density and genotypes for root and shoot growth inhibition parameter of the two weed species, the two factors were illustrated separately into two graphs in figures 1 and 2. Regressions were performed with MINITAB 17 software. The vectorization of the different roots was made with DART software (Data Analysis of Root Tracings). The analysis of root architecture data was performed using the R software called architect from the archiDART package (Delory et al., 2016). This software calculates common root architecture parameters and performs $\mathrm{XY}$ plotting of the vectorized root system.

\section{RESULTS}

\subsection{Allelopathic activity of barley against weeds}

In both weed species, great brome and common chickweed, a growth inhibition was observed after 10 days of seedling growth on the same agar medium on which barley seedlings had first developed (Figures 1 and 2). The barley root allelochemicals had a significant inhibitory activity from the lowest applied density of barley on root $\left(\mathrm{F}_{6: 85}=37.81 ; p<0.001\right)$ and shoot growth $\left(\mathrm{F}_{6 ; 85}=25.39 ; p<0.001\right)$ of common chickweed, and on root growth $\left(\mathrm{F}_{6 ; 85}=17.22 ; p<\right.$ 0.001 ) of great brome when compared to the control. However, no significant difference was observed in the shoot growth inhibition of great brome $\left(\mathrm{F}_{6: 85}=0.87\right.$; $p=0.519)$ as compared to the control. The results also showed that this effect depends on the number of barley seedlings: as barley density increased from 5 to 12 and 16 seeds/beaker, the root growth inhibition of great brome and common chickweed increased linearly.

For all densities, the inhibition rates were higher on root growth than on shoot growth. For example, the six barley genotypes reduced root growth of great brome and common chickweed by $45 \%$ and $62 \%$ and shoot by 5 and $27 \%$, respectively when using 16 barley seeds/beaker. This effect was also higher in common chickweed than in great brome.

When comparing barley genotypes, both weed species responded differentially to the allelopathic compounds of barley $\left(\mathrm{F}_{5: 72}=7.82 ; p<0.001\right.$ for root growth inhibition of great brome, and $\mathrm{F}_{5 ; 72}=26.86$; $p<0.001 ; \mathrm{F}_{5,72}=6.19 ; p<0.001$ for root and shoot growth inhibition of common chickweed, respectively), except for the shoot growth of great brome $\left(\mathrm{F}_{5 ; 72}=0.82\right.$; $p=0.234$ ) (Figures 1 and 2). Overall, the inhibitory activity of 'Saudi' and 'Ardhaoui' was higher than that of 'Manel' and 'Tej'. 

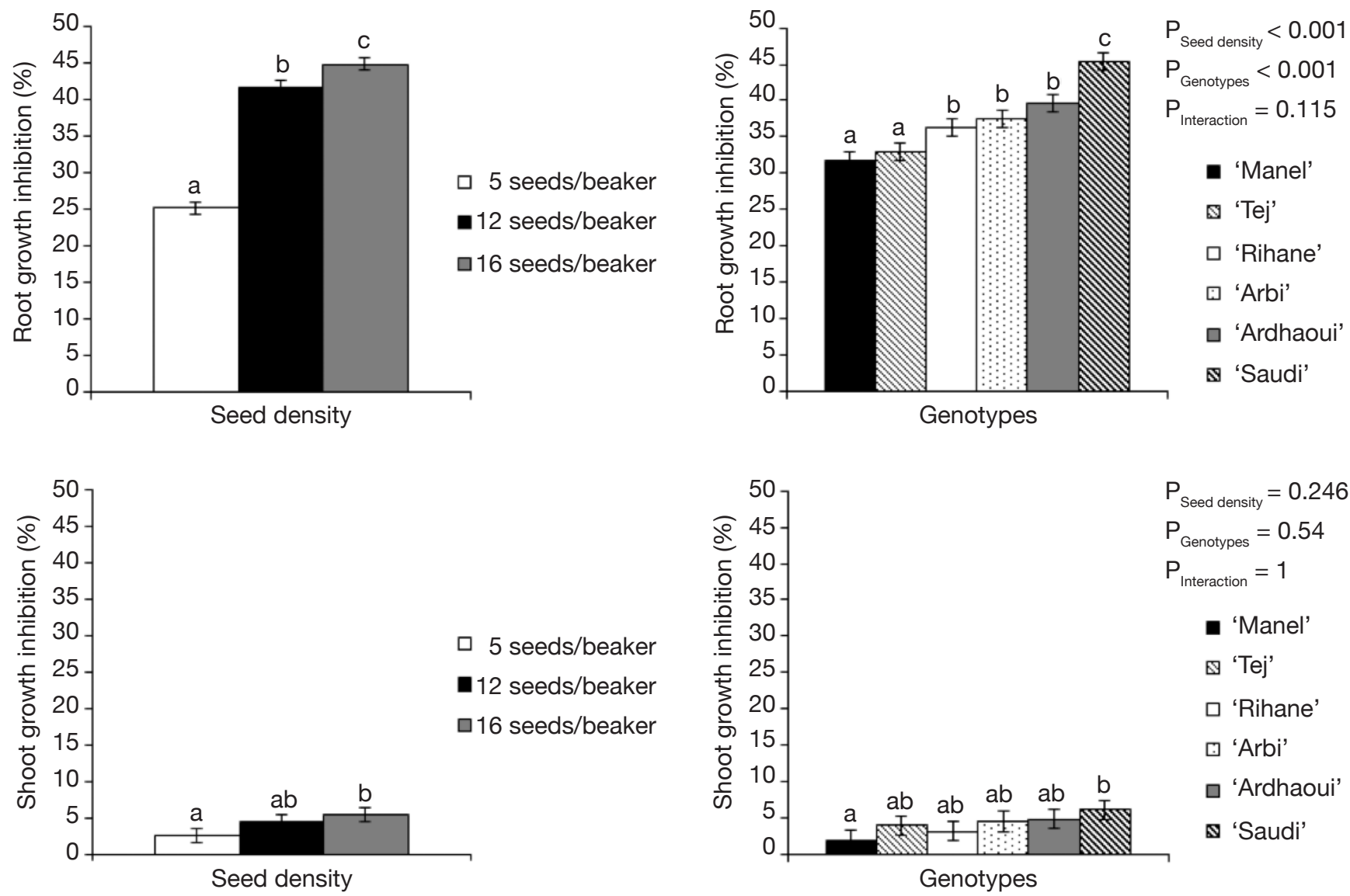

Figure 1. Root and shoot growth inhibition (\%) of great brome seedlings after 10 days exposure to root allelochemicals of six barley genotypes grown with three densities - Taux d'inhibition de la croissance des racines et des pousses (\%) des plantules du grand brome après 10 jours d'exposition aux allélochimiques racinaires de six génotypes d'orge cultivés avec trois densités.

Bars represent standard errors of the mean and different letters indicate significant differences at $p<0.05$ according to LSD test - les barres verticales indiquent les erreurs standards des moyennes et les différentes lettres indiquent une différence significative à $\mathrm{p}<0,05$ selon le test de PPDS.

The root allelopathic compounds released by 'Ardhaoui' reduced significantly the total root length of great brome seedlings as compared to the control $\left(\mathrm{F}_{1 ; 7}=33.95 ; p<0.001\right)$ (Table 2). To a large extent, this effect is caused by a reduction of the primary root length $\left(\mathrm{F}_{1: 7}=32.90 ; p<0.001\right)$, first- $\left(\mathrm{F}_{1: 7}=20.00 ; p<\right.$ $0.001)$ and second-order $\left(\mathrm{F}_{1 ; 7}=7.66 ; p=0.008\right)$ lateral root length.

Moreover, the treated seedlings of great brome exhibited a lower branching degree. The number of the first- $\left(\mathrm{F}_{1: 7}=26.02 ; p<0.001\right)$ and second-order $\left(F_{1 ; 7}=13.83 ; p=0.001\right)$ lateral roots was significantly reduced (which explains a lower density of secondorder lateral roots).

These results revealed that all the root traits of great brome are sensitive to barley allelochemicals.

\subsection{Allelopathic activity of barley against barley of the same or different genotype}

The self-inhibitory effect of barley root and shoot was significant, except for root and shoot growth in the " 'Ardhaoui'-'Ardhaoui'” combination (Table 3). This effect was more pronounced on root than on shoot growth (Figure 3). By comparing the effects within the same genotype or between two different barley genotypes, the results indicated that the inhibition rate of root or shoot growth was significantly different when comparing the " 'Ardhaoui'-"Ardhaoui' " combination with the "'Ardhaoui'-'Manel" " combination. This is not the case when comparing the "Manel''Manel'" and " 'Manel'-"Ardhaoui'" combinations. In particular, root inhibition rates observed in the 

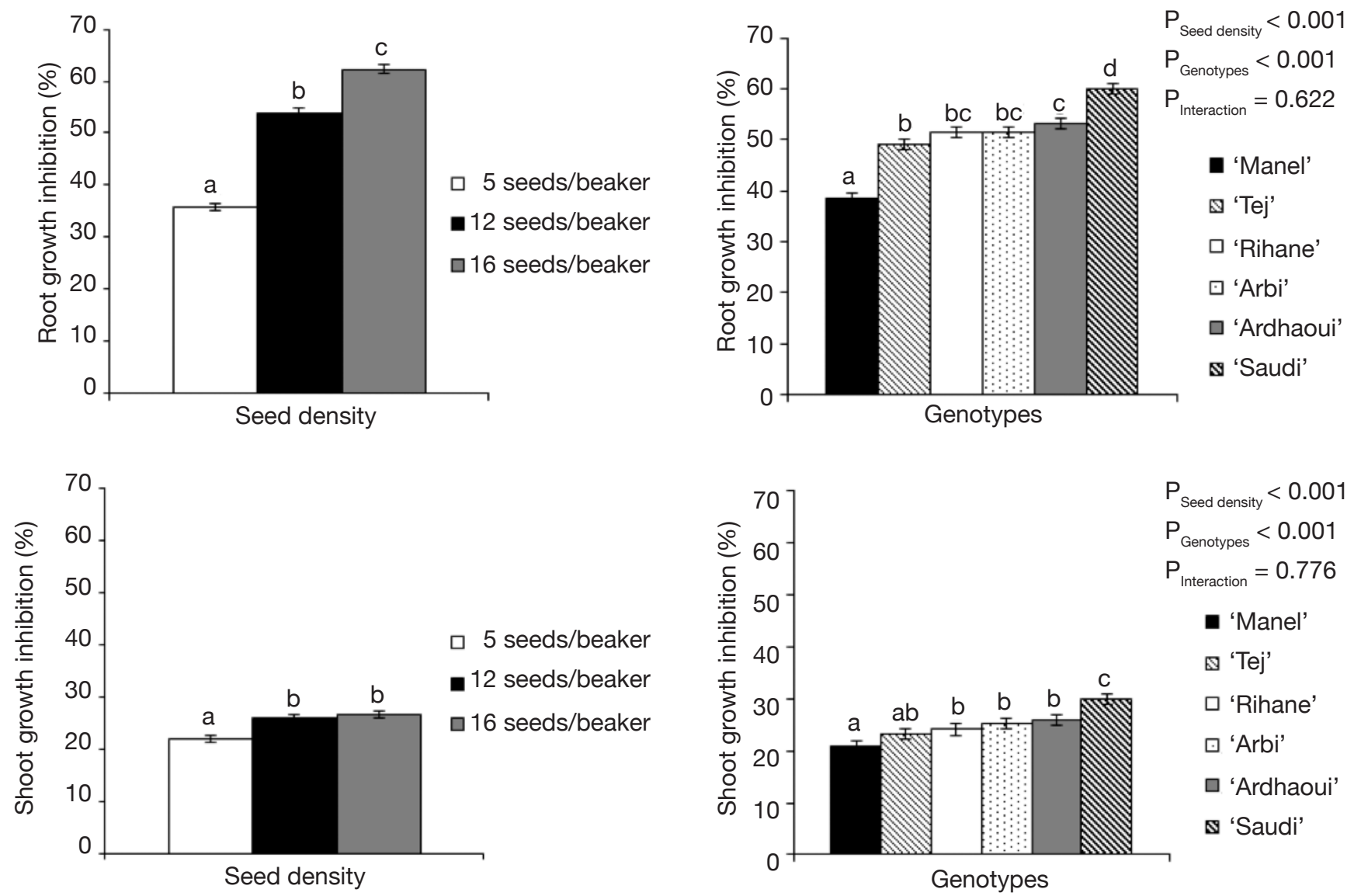

Figure 2. Root and shoot growth inhibition (\%) of common chickweed seedlings after 10 days exposure to root allelochemicals of six barley genotypes grown with three densities - Taux d'inhibition de la croissance des racines et des pousses (\%) des plantules de la stellaire intermédiaire après 10 jours d'exposition aux allélochimiques racinaires de six génotypes d'orge cultivés avec trois densités.

Bars represent standard errors of the mean and different letters indicate significant differences at $p<0.05$ according to LSD test - les barres verticales indiquent les erreurs standards des moyennes et les différentes lettres indiquent une différence significative à $\mathrm{p}<0,05$ selon le test de PPDS.

Table 2. Effect of barley root allelochemicals on the root system architecture (RSA) of great brome seedlings - Effet des allélochimiques racinaires d'orge sur l'architecture du système racinaire (ASR) des plantules du grand brome.

\begin{tabular}{lll}
\hline Trait & Control & ${ }^{\text {'Ardhaoui' }}$ \\
\hline Total root length $(\mathrm{cm})$ & $5.40 \pm 0.129^{\mathrm{a}}$ & $3.11 \pm 0.047^{\mathrm{b}}$ \\
\hline Primary root length $(\mathrm{cm})$ & $4.01 \pm 0.085^{\mathrm{a}}$ & $2.56 \pm 0.038^{\mathrm{b}}$ \\
Total length of first-order lateral roots $(\mathrm{cm})$ & $1.10 \pm 0.047^{\mathrm{a}}$ & $0.42 \pm 0.028^{\mathrm{b}}$ \\
\hline Total length of second-order lateral roots $(\mathrm{cm})$ & $0.02 \pm 0.002^{\mathrm{a}}$ & $0.01 \pm 0.001^{\mathrm{b}}$ \\
Number of first-order lateral roots & $4.06 \pm 0.191^{\mathrm{a}}$ & $1.17 \pm 0.073^{\mathrm{b}}$ \\
Number of second-order lateral roots & $0.17 \pm 0.015^{\mathrm{a}}$ & $0.02 \pm 0.004^{\mathrm{b}}$ \\
\hline Density of first-order lateral roots $\left(\mathrm{cm}^{-1}\right)$ & $0.67 \pm 0.015^{\mathrm{a}}$ & $0.34 \pm 0.027^{\mathrm{b}}$ \\
\hline Growth rate of the root system $\left(\mathrm{cm} \cdot \mathrm{day}^{-1}\right)$ & $0.51 \pm 0.013^{\mathrm{a}}$ & $0.30 \pm 0.005^{\mathrm{b}}$ \\
\hline
\end{tabular}

Values are means \pm standard error and different letters indicate significant differences at $p<0.05$ according to LSD test - les valeurs sont des moyennes \pm erreurs standards et les différentes lettres indiquent des différences significatives à $\mathrm{p}<0,05$ selon le test de PPDS.
" 'Manel'-'Manel'" (15\%) or " 'Ardhaoui'-'Manel' " (24\%) combinations were significantly higher than in the "Ardhaoui'"Ardhaoui'" (7\%) or “"Manel'"Ardhaoui'," (12\%) combinations.

\subsection{Allelopathic activity of great brome against itself and against barley}

The results (Figure 4) showed that compounds produced by the great brome roots reduced significantly root growth $\left(\mathrm{F}_{1: 8}=13.23 ; p<0.001\right.$ for "great brome-great brome", $\mathrm{F}_{1 ; 8}=127.45 ; p<0.001$ for " great brome-'Manel" " and $\mathrm{F}_{1 ; 8}=53.04$; 
Table 3. Analysis of variance (ANOVA) of root and shoot length of two barley genotypes grown on media pre-colonised by the same genotype, or the alternative genotype, and with those earlier seedlings manually removed - Analyse de la variance (ANOVA) de la longueur des racines et des pousses de deux génotypes d'orge cultivés sur un milieu pré-colonisé par le même génotype ou un génotype différent, dont les plantules ont été manuellement retirées.

\begin{tabular}{|c|c|c|c|c|}
\hline \multirow[t]{2}{*}{ Factor } & \multicolumn{4}{|c|}{ Barley donor-receiver genotype combination } \\
\hline & “ 'Manel'-'Manel' " & " 'Ardhaoui'-'Manel'" & " 'Ardhaoui'-'Ardhaoui" " & " 'Manel'-'Ardhaoui" " \\
\hline \multicolumn{5}{|l|}{ Root length } \\
\hline $\begin{array}{l}\text { F values } \\
\mathrm{df} \\
p \text { value }\end{array}$ & $\begin{array}{l}17.87 \\
1 ; 10 \\
<0.001\end{array}$ & $\begin{array}{l}48.81 \\
1 ; 10 \\
<0.001\end{array}$ & $\begin{array}{l}3.49 \\
1 ; 10 \\
0.065\end{array}$ & $\begin{array}{l}10.28 \\
1 ; 10 \\
0.002\end{array}$ \\
\hline \multicolumn{5}{|c|}{ Shoot length } \\
\hline $\begin{array}{l}\text { F values } \\
\text { df } \\
p \text { value }\end{array}$ & $\begin{array}{l}4.55 \\
1 ; 10 \\
0.036\end{array}$ & $\begin{array}{l}71.85 \\
1 ; 10 \\
<0.001\end{array}$ & $\begin{array}{l}2.20 \\
1 ; 10 \\
0.141\end{array}$ & $\begin{array}{l}7.82 \\
1 ; 10 \\
0.006\end{array}$ \\
\hline
\end{tabular}

df: degrees of freedom - degrés de liberté.

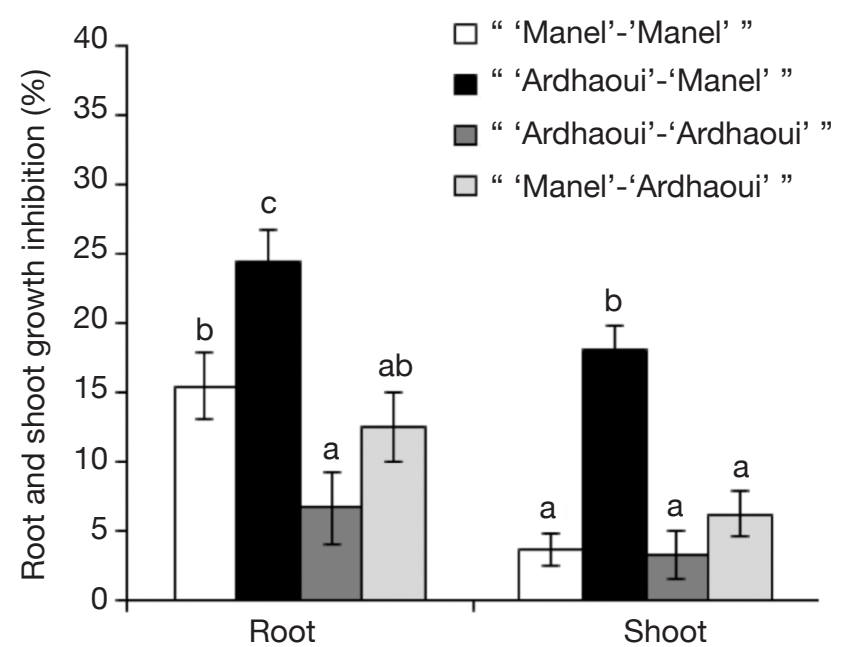

Figure 3. Root and shoot growth inhibition (\%) of barley seedlings from two genotypes after 10 days exposure to its own allelochemicals or those of the alternative genotypes - Taux d'inhibition de la croissance des racines et des pousses (\%) des plantules de deux génotypes d'orge après 10 jours d'exposition aux allélochimiques du même ou de génotypes différents.

Bars represent standard errors of the mean and different letters indicate significant differences at $p<0.05$ according to LSD test - les barres verticales indiquent les erreurs standards des moyennes et les différentes lettres indiquent une différence significative à $\mathrm{p}<0,05$ selon le test de PPDS.

$p<0.001$ for " great brome- "Ardhaoui'") of the receiver plants after 10 days as compared to the control. The same trend was obtained for shoot growth compared to the control $\left(\mathrm{F}_{1: 8}=41.22 ; p<0.001\right.$ for "great brome-'Manel" " and $\mathrm{F}_{1 ; 8}=22.93 ; p<0.001$ for " great brome-"Ardhaoui',"), except for the shoot growth of " great brome-great brome" $\left(\mathrm{F}_{1 ; 8}=3.49\right.$;

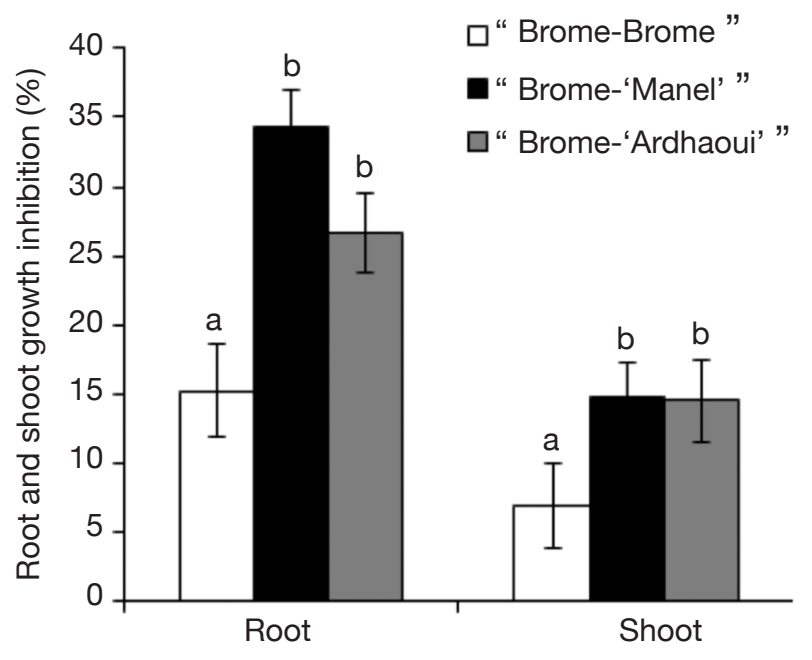

Figure 4. Root and shoot growth inhibition (\%) in great brome and two genotypes of barley seedlings after 10 days exposure to root allelochemicals of great brome - Taux d'inhibition de la croissance des racines et des pousses (\%) des plantules du grand brome et de deux génotypes d'orge après 10 jours d'exposition aux allélochimiques du grand brome.

Bars represent standard errors of the mean and different letters indicate significant differences at $p<0.05$ according to LSD test - les barres verticales indiquent les erreurs standards des moyennes et les différentes lettres indiquent une différence significative à $\mathrm{p}<0,05$ selon le test de PPDS.

$p=0.065)$. In these experiments, alloinhibition rates were greater than autoinhibition rates, especially in root, although both (root and shoot growth) were significant. The results also show that growth inhibition of barley by great brome root compounds was similar between the two genotypes 'Manel' and 'Ardhaoui'. 


\subsection{Relation between root vigor and toxicity of barley root exudates}

As root elongation rate differed between barley genotypes, the question was raised concerning the possible correlation between root vigor (as assessed by root length) and inhibitory activity. No significant correlation was obtained between barley root length after 7 days and its inhibitory action against the great brome $\left(\mathrm{r}^{2}=0.005, p=0.91\right)$ and the common chickweed $\left(\mathrm{r}^{2}=0.15, p=0.52\right)$ species (Figure 5). In conclusion, the observed genotypic effect is not linked to differential root growth rates between genotypes.

\subsection{Effect of the growing medium $\mathrm{pH}$ on phytotoxicity}

The first objective of this study is to show the $\mathrm{pH}$-variation of the water agar medium after 7 days of the growth of donor species. Thereby, the $\mathrm{pH}$-medium after the initial growth period of 'Ardhaoui' seeds, and before the great brome seeds were introduced, was determined in the absence and in the presence of the potassium phosphate buffer. In the absence of this buffer, the culture medium has initially a $\mathrm{pH}$ of 6.10 (control). After 7 days, this $\mathrm{pH}$ reached a value of 4.51 and 4.12 respectively in beakers receiving 5 and 16 'Ardhaoui' seedlings. The $\mathrm{pH}$ of the medium was significantly different $\left(\mathrm{F}_{2 ; 9}=357.51 ; p<0.001\right)$ in the presence of 'Ardhaoui' genotype compared to the control. However, in the presence of the potassium phosphate buffer, the $\mathrm{pH}$ values of the medium were 6.11 and 6.13 before sowing 5 and 16 'Ardhaoui' seedlings, respectively. After 7 days of growth, $\mathrm{pH}$ reached respectively a value of 6.09 and 5.98. In these conditions, the difference between these $\mathrm{pH}$ values in day 0 and day 7 was not significant $\left(\mathrm{F}_{1: 5}=5.02\right.$; $p=0.066$ and $\mathrm{F}_{1: 5}=3.90 ; p=0.096$ using 5 and 16 'Ardhaoui' seedlings, respectively). Buffering effect of the potassium phosphate was sufficient to maintain stable the acidity of the water agar.

The effect (neutral, stimulatory or inhibitory) of the addition of the potassium phosphate buffer to the water-agar medium on the growth of donor seedlings was assessed. Results showed that this buffer had no significant influence on root and shoot growth of 'Ardhaoui' seedlings when compared to the control (Figure 6).

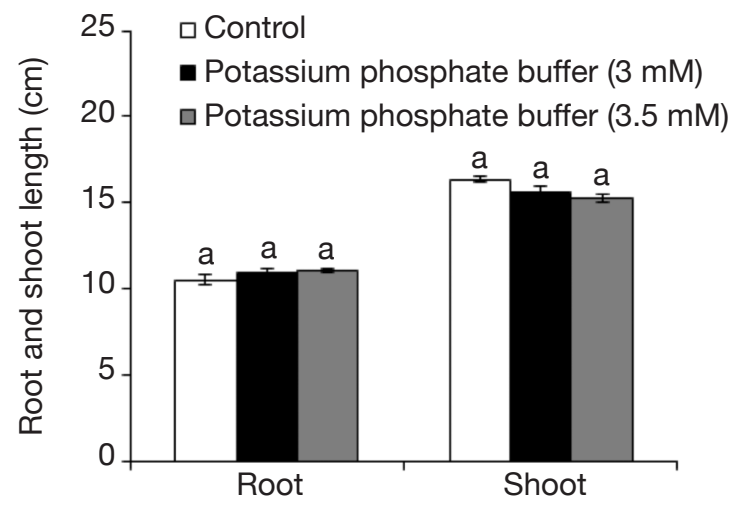

Figure 6. Effect of the addition of potassium phosphate buffer on the growth of barley 'Ardhaoui' seedlings - Effet de l'addition du tampon phosphate de potassium sur la croissance des plantules d'orge d' 'Ardhaoui'.

Bars represent standard errors of the mean and different letters indicate significant differences at $p<0.05$ according to LSD test - les barres verticales indiquent les erreurs standards des moyennes et les différentes lettres indiquent une différence significative à $\mathrm{p}<0,05$ selon le test de PPDS.
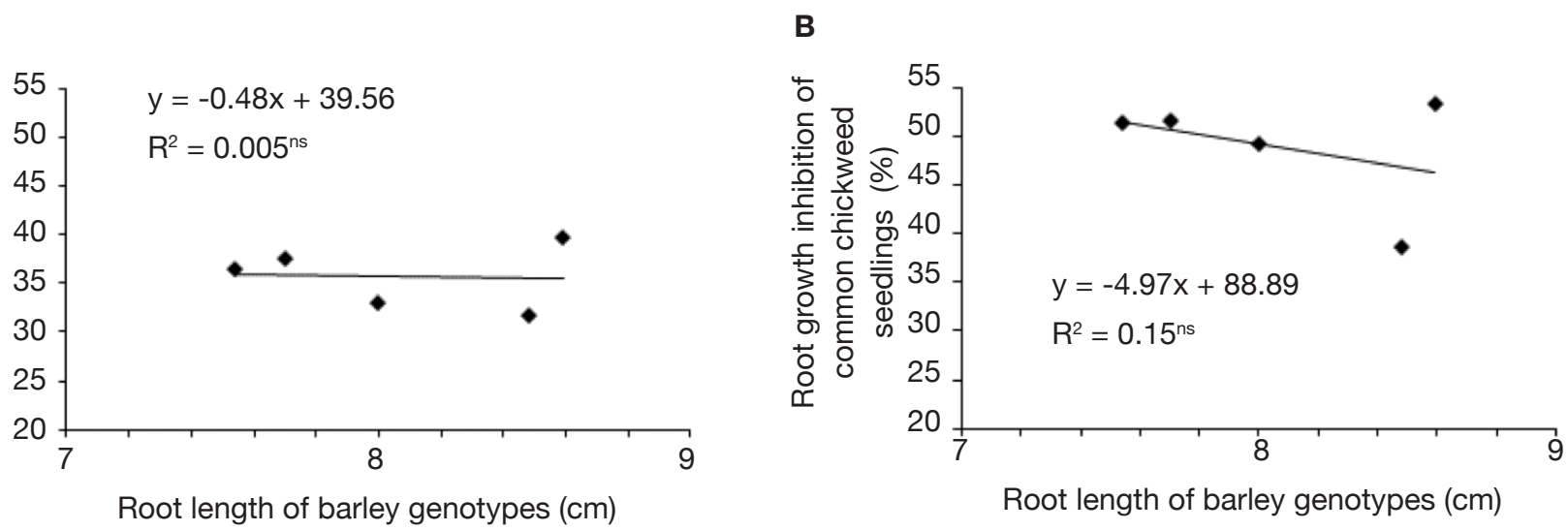

Figure 5. Correlation between the root length of the five Tunisian barley genotypes and their inhibitory action on the root of great brome (A) and common chickweed $(\mathbf{B})$ seedlings - Corrélation entre la longueur des racines des cinq génotypes d'orge tunisienne et leur action inhibitrice sur les racines des plantules du grand brome $(\boldsymbol{A})$ et de la stellaire intermédiaire (B).

ns: $p>0.05$. 
In a second experiment (Figure 7), growth inhibition of great brome by the barley genotype 'Ardhaoui' was studied in the presence or absence of potassium phosphate buffer in the medium. Regarding root growth after 10 days, a significant inhibition was observed as compared to the control and this is true in both the presence and absence of the buffer $\left(\mathrm{F}_{4: 58}=96.71 ; p<0.001\right)$. This effect was however not significant for shoot growth inhibition $\left(\mathrm{F}_{4: 58}=0.89\right.$; $p=0.473)$. The inhibition rates were slightly reduced by the presence of the buffer for the two barley seed densities (5 and 16 seeds/beaker), but differences between the two treatments (i.e. in the presence or in the absence of the buffer) were not significant for the two morphological parameters.

\section{DISCUSSION}

The 'equal-compartment-agar method' (ECAM) developed by Wu et al. (2000) is a common tool for investigating plant-to-plant allelopathy and these authors initially adopted this co-culture method to determine the allelopathic potential of wheat root exudates towards Lolium rigidum Gaudin. They argued that 'ECAM' limits competition effects e.g. for nutrient resources as donor and receiver species are co-cultivated in nutrient-free water agar medium and for light by inserting a paperboard between the two species ( $\mathrm{Wu}$ et al., 2000) or by changing seed density and sowing patterns (Asaduzzaman et al., 2014). However, other competition for resources may persist, e.g. for space needed for root development (Caffaro et al., 2013), and changes in the atmosphere during co-culture may also participate to the observed changes in plant growth. Consequently, we cannot prove the role of the root exudates in the observed interactions between co-cultivated plants. Indeed, the release of VOCs by the above and belowground parts of the barley plant has been demonstrated and their possible roles in biotic interactions have been discussed (Ninkovic, 2003; Gfeller et al., 2013).

Our work aimed at addressing these methodological limitations by growing the donor and receiver plants one after the other, instead of together, in the same beaker. Based on previous work, we have shown that allelochemicals were increasingly toxic over time against great brome and ryegrass (Lolium rigidum) after removal of barley seedlings (Bouhaouel et al., 2015) indicating the persistence of the allelopathic effect. For this reason, our bioassay named "seedlingafter-seedling agar method" presents the two following interests:

- the competition between donor and receiver plants is reduced because they are grown sequentially and do not compete concomitantly for resources,

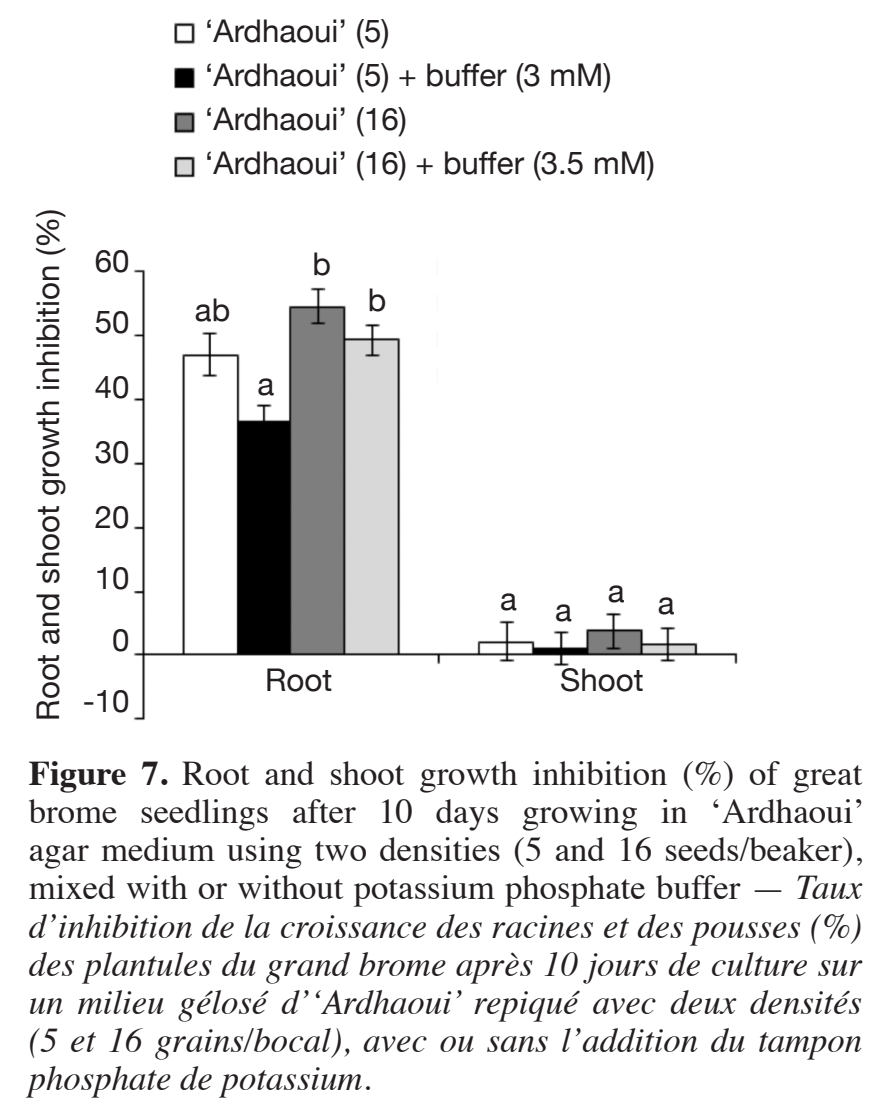

Bars represent standard errors of the mean and different letters indicate significant differences at $p<0.05$ according to LSD test - les barres verticales indiquent les erreurs standards des moyennes et les différentes lettres indiquent une différence significative à $\mathrm{p}<0,05$ selon le test de PPDS.

- the method is specific to water-soluble compounds released by roots or resulting from their degradation, due to the renewal of the atmosphere of the container between the two successive cultures. The "seedlingafter-seedling agar method" also allowed to test the effect of barley allelochemicals on growth of great brome and vice-versa in a more advanced stage of growth as compared to the "seed-after seed" (Bouhaouel et al., 2015). Another advantage of this method was to test the effect of barley alloinhibition on common chickweed (S. media), which was not considered by our previous studies. However, it must be acknowledged that the sequential cultivation of the donor and receiver seedlings is a case of interaction that cannot be fully transposed to field situations where both species cohabit, potentially influencing each other in a synchronous manner.

After 10 days, growth of great brome and common chickweed was significantly reduced by the preceding cultivation of barley in the same beaker, in a densitydependent manner (Figures 1 and 2). The inhibitory 
action of barley roots showed a more pronounced effect on the roots than on the shoots of the receiver species. Similar findings were obtained in several tests (Ben-Hammouda et al., 2001; Oueslati et al., 2005), and it is assumed that this part of the plant is the primary target of the exuded allelochemicals (ViardCrétat et al., 2009). In this paper, further attention was payed to investigate the qualitative changes of the root system, i.e. the effects on root architecture in great brome exposed to barley root allelochemicals (Table 2). A conclusion is that allelochemicals not only inhibit root growth, but also have an impact on root architecture, i.e. changes in total root length and degrees of branching are observed as compared to the untreated seedlings. All the measured root traits of great brome were sensitive to barley allelochemicals. Allelopathic effects were expected to have subtle consequences on nutrient use efficiency in receiver plants.

The barley genotypes exhibited a differential allelopathic activity against weeds (great brome and common chickweed), with barley landraces 'Saudi' and 'Ardhaoui' being more toxic than barley varieties 'Manel' and 'Tej' (Figures 1 and 2). A variation in allelopathic activity was similarly reported in different barley germplasms (Baghestani et al., 1999; Bertholdsson, 2004; Oveisi et al., 2008). On the other hand, both weed species (great brome and common chickweed) do not react in the same way against the barley root compounds. Indeed, the growth of common chickweed seedlings was more affected than that of great brome (Figures 1 and 2), confirming its sensitivity to barley root allelochemicals as reported by Overland (1966).

The allelopathic potential of barley root exudates against the two weed species has no apparent relationship with their root sizes, suggesting that longer roots may not release higher amounts of, or more toxic, allelochemicals (Figure 5). These results are consistent with previous reports in rice (Jensen et al., 2001) and barley (Bertholdsson, 2004), concluding that allelopathy in barley is controlled by genetic factors distinct from those controlling root development. The effect of the $\mathrm{pH}$ of the growing medium on barley phytotoxicity was investigated by the addition of the potassium phosphate buffer. This buffer had no effect on the growth of barley seedlings (Figure 6), but had slightly reduced the inhibitory action of the barley root allelochemicals (Figure 7), nevertheless the differences between the two treatments (i.e. in the presence or in the absence of the buffer) were not significant. Consequently, no clear conclusions can be drawn concerning the role of $\mathrm{pH}$ variation in the inhibitory action. The molecules exuded in the culture medium seem to be the main actors in the allelopathic barley potential.
The present research also showed that barley root exudates cause autotoxicity, but interestingly the magnitude of this effect depended on the combination of the donor and receiving genotypes, which may be of the same or different genotypes (Figure 3). This confirmed previous observations in wheat by $\mathrm{Wu}$ et al. (2007) who distinguished between "varietal allelopathy" (interaction between two different varieties) and "varietal autotoxicity" (interaction within the same varieties).

The root growth inhibition was higher when 'Manel' (15\% and 24\% in "'Manel'-'Manel' " and " 'Ardhaoui'-'Manel'" respectively) was the receiver species of allelochemicals compared to 'Ardhaoui' (7\% and $12 \%$ in " 'Ardhaoui'-'Ardhaoui'" and "'Manel'"Ardhaoui'" respectively). This might indicate that 'Manel' is a sensitive variety to root compounds because it is less able to detoxify the allelochemicals produced by 'Ardhaoui'.

This study provides a laboratory-based evidence of the allelopathic activity of great brome root exudates against barley particularly on roots (Figure 4). At this level, 'Manel' (low allelopathic potential) and 'Ardhaoui' (high allelopathic potential) genotypes seem to react in a similar way to great brome root allelochemicals, whilst noting a slightly greater resistant action with 'Ardhaoui'. The root exudates of this weed also cause lower autotoxicity compared to its alloinhibition activity. Similarly, the same trend was obtained in barley by comparing its auto- and alloinhibition potential (Figure 4). All these results indicated that there was an inter- and intraspecies difference in allelochemicals recognition and this discrimination suggests that this phenomenon could be implicated in the mechanisms of plant defense. For example, the cinnamic acid - an allelochemical of cucumber roots exudates - added to a nutritive solution showed an autotoxic effect by inducing an oxidative stress accompanied by the death of cucumber root cells, but not in Cucurbita ficifolia Bouché, a species of the same family (Ding et al., 2007).

Increasing the ratio between allotoxicity and autotoxicity, could be achieved by plants using at least three mechanisms: no or lower affinity of the toxic compounds with the molecular targets, detoxication by degradation of the toxic compounds, sequestration of the toxic compounds preventing contact with their molecular target site. Several researches lend support to the mechanisms of detoxication (Baerson et al., 2005) or sequestration (Duke et al., 1994). To the best of our knowledge, there is no research demonstrating the two first hypotheses but further work is clearly needed to unravel the action mechanisms of allelopathy and their diversity among the many combinations of plant species, particularly those between weeds and important crop species. 


\section{Acknowledgements}

During this work, the first author was recipient of a $\mathrm{PhD}$ fellowship of the Erasmus Mundus Averroès Partnerships Action of the European Commission. This work was funded by internal grants of Gembloux Agro-Bio Tech, University of Liège.

\section{Bibliography}

Asaduzzaman M.et al., 2014. Laboratory bioassay for canola (Brassica napus) allelopathy. J. Crop Sci. Biotechnol., 17, 267-272.

Baerson S.R. et al., 2005. Detoxification and transcriptome response in Arabidopsis seedlings exposed to the allelochemical benzoxazolin-2(3H)-one. J. Biol. Chem ., 280, 21867-21881.

Baghestani A., Lemieux C., Leroux G.D. \& Baziramakenga R., 1999. Determination of allelochemicals in spring cereal cultivars of different competitiveness. Weed Sci., 47, 498-504.

Belz R.G., 2007. Allelopathy in crop/weed interactions - an update. Pest Manage. Sci., 63, 308-326.

Ben-Hammouda M., Ghorbal H., Kremer R.J. \& Oueslati O., 2001. Allelopathic effects of barley extracts on germination and seedlings growth of bread and durum wheat. Agronomie, 21, 65-71.

Bertholdsson N.O., 2004. Variation in allelopathic activity over 100 years of barley selection and breeding. Weed Res., 44, 78-86.

Blum U., Dalton B.R. \& Shann J.R., 1985. Effects of ferulic and p-coumaric acids in nutrient culture of cucumber leaf expansion as influenced by pH. J. Chem. Ecol., 11, 1567-1582.

Bouhaouel I. et al., 2015. Allelopathic and autotoxicity effects of barley (Hordeum vulgare L. ssp. vulgare) root exudates. BioControl, 60, 425-436.

Brix H., Dyhr-Jensen K. \& Lorenzen B., 2002. Root-zone acidity and nitrogen source affects Typha latifolia L. growth and uptake kinetics of ammonium and nitrate. J. Exp. Bot., 53, 2441-2450.

Caffaro M.M., Vivanco J.M., Botto J. \& Rubio G., 2013. Root architecture of Arabidopsis is affected by competition with neighbouring plants. Plant Growth Regul., 70, 141-147.

Chon S.U., Jennings J.A. \& Nelson C.J., 2006. Alfalfa (Medicago sativa L.) autotoxicity: Current status. Allelopath. J., 18, 57-80.

Chon S.U. \& Nelson C.J., 2010. Allelopathy in compositae plants. A review. Agron. Sustain. Dev., 30, 349358.

Chou C.H., 1999. Roles of allelopathy in plant biodiversity and sustainable agriculture. Crit. Rev. Plant Sci., 18, 609-636.

Darrah P.R., 1993. The rhizosphere and plant nutrition: a quantitative approach. Plant Soil, 155/156, 1-20.
Delory B.M. et al., 2016. archiDART: an R package for the automated computation of plant root architectural traits. Plant Soil, 398, 351-365.

Ding J. et al., 2007. Physiological basis of different allelopathic reactions of cucumber and figleaf gourd plants to cinnamic acid. J. Exp. Bot., 58, 3765-3773.

Duke M.V. et al., 1994. Localization of artemisinin and artemisitene in foliar tissues of glanded and glandless biotypes of Artemisia annua. Int . J. Plant Sci., 155, 365373.

El Faleh M., Maamouri A., Deghais M. \& El Ahmed A., 1985. Three new barley cultivars from Tunisia. Rachis, 4, 50-51.

El Felah M., 2011. L'orge en Tunisie : historique, état actuel et perspectives. Ann. INRAT, 84, 7-34.

Fageria N.K., Baligar V.C. \& Wright R.J., 1989. Growth and nutrient concentrations of alfalfa and common bean as influenced by soil acidity. Plant Soil, 119, 331-333.

Gfeller A. et al., 2013. Characterization of volatile organic compounds emitted by barley (Hordeum vulgare L.) roots and their attractiveness to wireworms. J. Chem. Ecol., 39, 1129-1139.

Gharbi M.S. \& El Felah M., 2013. Les céréales en Tunisie : plus d'un siècle de recherche variétale. Ann. INRAT, 86, 4568.

Gubbels G.H. \& Kenaschuk E.O., 1989. Agronomic performance of flax grown on canola, barley and flax stubble with and without tillage prior to seeding. Can.J. Plant Sci., 69, 31-38.

Hammami Z. et al., 2016. Evaluation of performance of different barley genotypes irrigated with saline water in South Tunisian Saharan conditions. Environ. Exp. Biol., 14, 15-21.

Hinsinger P., Plassard C., Tang C. \& Jaillard B., 2003. Origins of root-mediated $\mathrm{pH}$ changes in the rhizosphere and their responses to environmental constraints: A review. Plant Soil, 248, 43-59.

Hue N.V., Vega S. \& Silva J.A., 2001. Manganese toxicity in a Hawaiian oxisol affected by soil $\mathrm{pH}$ and organic amendments. Soil Sci. Soc. Am. J., 65, 153-160.

Inderjit S., 2005. Soil microorganisms: An important determinant of allelopathic activity. Plant Soil, 274, 227-236.

Jensen L.B. et al., 2001. Locating genes controlling allelopathic effects against barnyardgrass in upland rice. Agron. J., 93, 21-26.

Kellermeier F., Chardon F. \& Amtmann A., 2013. Natural variation of Arabidopsis root architecture reveals complementing adaptive strategies to potassium starvation. Plant Physiol., 161, 1421-1432.

Kremer R. \& Ben-Hammouda M., 2009. Allelopathic plants. 19. Barley (Hordeum vulgare L.). Allelopath. J., 24, 225-242.

Lanoue A. et al., 2010. De novo biosynthesis of defense root exudates in response to Fusarium attack in barley. New Phytol., 185, 577-588. 
Nilsson M.C., 1994. Separation of allelopathy and resource competition by the boreal dwarf shrub Empetrum hermaphroditum Hagerup. Oecologia, 98, 1-7.

Ninkovic V., 2003. Volatile communication between barley plants affects biomass allocation. J. Exp. Bot., 54, 19311939.

Olofsdotter M., Jensen L.B. \& Courtois B., 2002. Improving crop competitive ability using allelopathy - an example from rice. Plant Breed., 121, 1-9.

Orman-Ligeza B. et al., 2013. Post-embryonic root organogenesis in cereals: branching out from model plants. Trends Plant Sci., 18, 459-467.

Oueslati O. et al., 2005. Barley autotoxicity as influenced by varietal and seasonal variation. J. Agron. Crop Sci., 191, 249-254.

Oveisi M. et al., 2008. Assessment of the allelopathic potential of 17 Iranian barley cultivars in different development stages and their variations over 60 years of selection. Weed Biol. Manage., 8, 225-232.

Overland L., 1966. The role of allelopathic substances in the 'smother crop' barley. Am. J. Bot., 53, 423-432.

Putnam A.R., 1985. Allelopathic research in agriculture: Past highlights and potential. In: Thompson A.C., ed. The chemistry of allelopathy: Biochemical interactions among plants. Washington: American Chemical Society, 1-8.

Rajan S.S.S. \& Ghani A., 1997. Differential influence of soil $\mathrm{pH}$ on the availability of partially sulphuric and phosphoric acidulated phosphate rocks II. Chemical and scanning electron microscopic studies. Nutr. Cycling Agroecosyst., 48, 171-178.
Rice E.L., 1984. Allelopathy. $2^{\text {nd }}$ ed. Orlando, FL, USA: Academic Press.

Rich S.M. \& Watt M., 2013. Soil conditions and cereal root system architecture: review and considerations for linking Darwin and Weaver. J.Exp. Bot., 64, 1193-1208.

Shamsi I.H., Wei K., Jilani G. \& Zhang G.P., 2007. Interactions of cadmium and aluminum toxicity in their effect on growth and physiological parameters in soybean. J. Zhejiang Univ. Sci. B, 8, 181-188.

Singh H.P., Batish D.R. \& Kohli R.K., 1999. Autotoxicity: concept, organisms and ecological significance. Crit. Rev. Plant Sci., 18, 757-772.

Singh K. \& Kayastha A.M., 2014. $\alpha$-amylase from wheat (Triticum aestivum) seeds: its purification, biochemical attributes and active site studies. Food Chem., 162, 1-9.

Souissi T., Belhadj Salah H. \& Latiri K., 2001. Brome in cereal crops: infestations and management. Invest. Agric., 42, 29-32.

Viard-Crétat F., Gallet C., Lefebvre M. \& Lavorel S., 2009. A leachate a day keeps the seedlings away: mowing and the inhibitory effects of Festuca paniculata in subalpine grasslands. Ann. Bot., 103, 1271-1278.

Wu H., Pratley J., Lemerle D. \& Haig T., 2000. Laboratory screening for allelopathic potential of wheat (Triticum aestivum) accessions against annual ryegrass (Lolium rigidum). Aust. J. Agric. Res., 51, 259-266.

Wu H. et al., 2007. Autotoxicity of wheat (Triticum aestivum L.) as determined by laboratory bioassays. Plant Soil, 296, 85-93.

(49 ref.) 